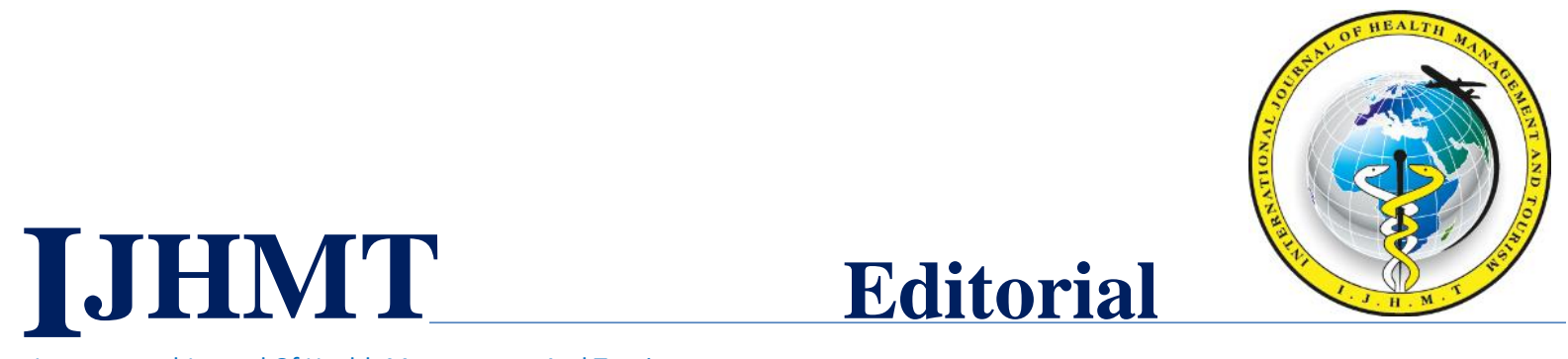

Internatıonal Journal Of Health Management And Tourism

\title{
A COMPARATIVE STUDY IN PUBLIC-PRIVATE HOSPITALS ABOUT EFFECTS OF PSYCHOLOGICAL CONTRACT ON EMPLOYEE PERFORMANCE ${ }^{1}$
}

\author{
Erhan KILINÇ ${ }^{1}$, H. Mustafa PAKSOY ${ }^{2}$ \\ $1 * \mathrm{Ph}$. D. Assit Prof. of Business Management Faculty, Selçuk Üniversitesi, TURKEY \\ ${ }^{2} \mathrm{Ph}$.D. Prof. of Business Management Faculty, University of Kilis 7 Aralık,TURKEY \\ *erhankilinc@selcuk.edu.tr
}

\begin{abstract}
The psychological contract is a set of mental expectations created by the individual, which is an unspoken agreement that reveals what the organizations and the workers expect from each other and whether these expectations are met. The main aim of this study was to determine the level of psychological contract expectations, level of satisfaction by the institution and breach of the psychological contracts of the health professionals working in public and private hospitals and to determine whether there is any difference between them. The universe of the study $(\mathrm{N}=5112)$ has been created healthcare services professionals (physicians, nurses, midwives, health technicians) at the public hospitals and private hospitals which operating in the center of Gaziantep City. It was applied questionnaire to total 1202 person (23.61\%) at between January-April 2015. The data were evaluated using the SPSS 15.0 program using frequency and percentage analyzes, factor analysis, significance test between two means (T test), analysis of variance (ANOVA), and correlation analysis. According to the results of the study, it was determined that the levels of psychological contract expectations and level of satisfaction by the institution of private hospital health workers were higher than those of public hospital health workers. It was determined that the level of psychological contract breach of public hospital healthcare workers is higher than that of private hospital health workers. A statistically significant negative correlation was found between psychological contract breach and employee performance ( $\mathrm{p}<0.01)$. Future studies in different cities will be important in measuring the impact of the psychological contract on health workers and comparing them with the results of this research. From this point of view, it is thought that the results obtained will give a light to future studies.
\end{abstract}

Keywords: psychological contract, employee performance, health care workers, public hospitals, private hospitals. 


\section{Introduction}

In a global world, businesses have been heavily influenced by technological developments, changing market conditions and industry relations, uncertainties in the economy and the wave of fluctuations and the desire to gain a competitive edge, this made them more complex and dynamic. Organizations must now develop new strategies, set new targets, working norms and working profiles to ensure competitiveness and durability. Under these conditions, organizations need to develop good relationships with employees to reach their goals and retain their qualified employees. On the other hand, although businesses have a well-equipped (knowledge, skill and experience) workforce, they can not achieve the performance they expect if they can not motivate them sufficiently (Cihangiroğlu and Şahin, 2010: 1; Işılak and Torun, 2012: 1; Akyüz and Karadal, 2014: 104; Kraft, 2008: 1; Türker and Karcığlu, 2010: 97; Coyle et al., 2008: 2).

Human behaviors as reflected in employee behaviors, are often unpredictable, difficult to understand and complex. Managers have a number of basic beliefs and thoughts about how employees should how to behave. These beliefs and thoughts, even if they are mistaken, form the basis of theirs management philosophies and understandings. For this reason, the knowledge of psychological theories that help employees to identify and understand is a necessity for managers who deal with many human problems. Many disciplines such as business, psychology, sociology and behavior have introduced a number of concepts, theories, theories and techniques to understand and explain human behavior in organizations (İşçi and Artan, 2010: 2). One of these concepts is the concept of "psychological contract" which is increasing in popularity especially after 2000's (George, 2009: 13; Kaldırımc1, 1987: 113). The psychological contract is a concept based on the relationship between employees and organizations, like many organizational behavioral topics (Lambert et al., 2003: 895). Today, the concept of psychological contract has attracted the attention of researchers and became a popular concept because it helps to understand the relationship between employee and employer (Mimaroğlu and Özgen, 2010: 1). This concept is a key issue in ensuring that employers and working relationships are at the highest level of compliance (Türker and Karcıoglu, 2010: 97; Coyle et al., 2008: 2).

\section{Literature Review}

\section{Psychological Contract}

Today, formal contracts between employees and employers in organizations are insufficient to explain many issues, with the regulation of the obligations of the parties concerned.In the minds of employees, they have a number of expectations beyond the written elements and relevant legal regulations in their employment contracts and they often do not express these expectations (Dikili and Bayraktaroğlu, 2013: 221; Bedük, 2014: 1). The psychological contract is a set of mental expectations created by the individual, which is an unspoken agreement that reveals what the organizations and the workers expect from each other and whether these expectations are met (Cihangiroğlu and Şahin, 2010: 1; Karcioğlu and Türker, 2010: 121). Psychological contract is a contract which has significant effect on verbal and written contracts although it is 
not verbal or written. Every employer and employee has a psychological contract that goes beyond the formal employment contract. This concept, which has recently been considered an important research topic has become a phenomenon in the literature (Cihangiroğlu and Şahin, 2010: 1,2; Cipd, 2005: 5).

There are two basic aspects of the psychological contract. Firstly; the behaviors and duties that the employer expects from the employee, such as commitment, honesty, compliance with business rules, doing quality work, making sacrifices related to work. Secondly; the material and spiritual factors that employee expects from the workplace, such as fairness, merit, equality, opportunities for development, reward, appreciation and motivation. In this respect, there is a reciprocity in the psychological contract between employers and employers. In addition, the concept of psychological contract plays a role of mediation between the employer and the employee in fulfillment of mental promises and obligations (Robinson and Rousseau, 1994: 247; İşçi and Artan, 2010: 3; Cipd, 2005: 5; Mimaroğlu and Özgen, 2008: 1; European Commission, 2006: 14).

When the characteristics of the psychological contract are evaluated, the following conclusions arise (Y1lmaz and Çelik, 2012: 9; Robinson and Rousseau, 1994: 246; Ceseroğlu and Tükeltürk, 2010: 4; Anderson and Schalk, 1998: 640; Bedük, 2014: 3). Psychological contract;

- It is not formal, it is relational, and its content consists mostly of emotional predispositions and obligations.

- It is individual and subjective; due to different interpretations of employees' events in the organization, they vary from individual to individual,

- It is based on the principle of reciprocity, due to a positive outcome expectation and commitment for both sides.

- It is based on a perceptual and emotional basis, not written or oral rules.

- It is dynamic and can change over time according to the individual's organizational experience.

- It is subjective, there are different and specific beliefs about what the parties expect from each other.

- Despite the mutual obligations and beliefs of the parties, it is not necessary for both parties to accept this contract.

Psychological contract breach is the inability of the contracting parties to fulfill mental promises or anticipations. This situation can have important consequences for both sides (employee and organization). Psychological contract breaches in organizations reveal situations such as frustration, resentment and reduced trust in mutual relations. Psychological contract breaches cause employees to experience some psychological problems, occuring unfairness, injustice and treachery, low performance and even staff resigning from work (Robinson and Rousseau, 1994: 247; İşçi and Artan, 2010: 3; Cipd, 2005: 5; Mimaroğlu and Özgen, 2008: 1; European Commission, 2006: 14). 


\section{Employee Performance}

Performance is the achievement degree to which an individual, a group, or an organization in a business and activity. Performance is a quantitative and qualitative concept that shows what is achieved and what is achievable for that job. In the literature, it is seen that the concept of performance in organizations is evaluated to two basic dimensions. Firstly, the individual performance of each individual employee; and the other is organizational performance on the whole. While performance in terms of individual is defined as the individual level of achievement of the in reaching the goal; organizational performance is defined as the level of realization of goods or services produced at a certain time (Tutar, et al., 2013: 141; Tengilimoğlu, et al., 2009: 322; Tutar and Altınöz, 2010: 201). In addition, individual performance is the result of a relationship between individual expectations and organizational goals (Tutar and Altınöz, 2010: 202).

In fact, the positive or negative discourse that employees say about the organization, the attitudes and behaviors they exhibit and the activities they perform reflect the level of employee performance (Şehitoğlu and Zehir, 2010: 96). Employee performance usually does not occur spontaneously; they are influenced by the attitudes and policies of businesses and managers. The high level of performance of employees depends on managers and organizations preparing for them a working environment, rewarding the work they do well and meeting their wishes and needs (Bekele et al., 2014; 145; Ripley, 2002; 1). Employees' perceptions and judgments related to workplace, managerial behaviors and work are highly influential on their individual performance. In these perceptions, the attitude and behaviors of the manager and the unit manager towards the employee are important (Ahmed et al., 2011; Prather, 2010; 1-2). Employee-manager relationships can have a major impact on how the performance appraisal process will be perceived. In these relationships, many factors can play such as first impressions, speech style and voice tone, personality conflicts, working habits and past experiences (Prather, 2010; 6).

In recent years, it is also seen that the number of studies examining the influence of performance and performance evaluation systems on the workforce has also increased. These studies show that there is a direct relationship between performance appraisal and employee satisfaction (Brown et al., 2010). In order to implement an effective performance appraisal system, companies need to consider interpersonal process and outcome justice. Low morale and productivity in enterprises, high absenteeism rates and high staff turnover stem from the failure to implement a fair performance appraisal process (Wright, 2004). Businesses need to pay attention to factors such as working conditions, paying, rewarding, job security, career management, training and development, cultural, social activities, supervision, discipline, organizational commitment and motivation for to keep the qualified workforce and increase employee performance (Türk, 2007: 76-81; Geylan, et al., 2013: 16-18, 96).

\section{Psychological Contract and Employee Performance in Health Sector}

Health care services are a type of service that is directly related to human life, does not accept mistakes and is not an alternative. For this reason, health services include inevitable 
responsibilities that must be addressed more sensitively than and as high as possible when compared to many services (Yorgun, et al., 2010: 353). However, healthcare facilities are laborintensive; and the human factor is crucial in the delivery and satisfaction of this service. Today, the need for qualified health workers of health institutions and organizations is increasing day by day and there are some problems in keeping the existing qualified personnel. It is necessary to take into account their performance and to evaluate it properly in order to solve these problems and to ensure that the employees work beyond their expectations. It will increase institutional efficiency and productivity provide opportunities such as making career for health workers, taking managerial duties, participating in decisions and declaring their ideas(Cihangiroğlu and Şahin, 2012: 64,69; Yavan, 2012: 1). Many professions in hospitals serve in a stressful and intensive work environment with the understanding of team work. Effective performance management is required for these occupational groups to be motivated towards hospital goals and for good performance performances. In this sense, performance management of health institutions has a strategic importance (Özer and Bakır, 2003: 117; Yorgun, et al., 2010: 355).

According to other sectors of the health sector, the rate of workplace change in employees, the frequency of psychological problems and the burnout syndrome are high; and job satisfaction is low. Although this sector on a professionalisation process of the last 15 years in Turkey; it seems that there are difficulties in correctly understanding the expectations of the employees of the health care institutions and meeting these expectations (İşçi and Artan, 2010: 112). However, it is also known that various psychological contracts breaches have been realized in the health sector. Some of those; the demand and enforcement of hospital managers to make overtime work for healthcare workers in terms of work intensity and staff absenteeism; that managers do not take adequate measures in the hospital so that health workers are not exposed to violence; the health worker is unable to charge a sufficient fee. The realization of psychological contract breaches in the health sector has negative effects on the quality of service and productivity in ensuring the continuity of these services. It is extremely important to avoid psychological contract breaches in order to solve these problems and to ensure that employees perform as expected. In the study conducted by Khalid, some of the new psychological contract attitudes are provided by hospital administrations for nurses improve their skills and make careers themselves (Khalid, 2003: 53). Therefore, the concept of psychological contract in the health sector is an important issue to be investigated.

This study provides important results in terms of providing better quality, more efficient and effective health service, increasing employee satisfaction, assisting hospital and hospital administrators (institutional) in organizing relations, increasing satisfaction of health service users (community) and leading new scientific studies.

\section{Researches on Psychological Contract and Employee Performance}

When literature studies are examined, psychological contract studies seem to focus on three main areas. These; whether the organization perception is possible, psychological contract and employment relation, psychological contract breach and its effect (Crossman, 2002: 64, Kidder 
and Buchholtz, 2002: 613, Rousseau, 2000: 1, Wellin, 2007: 30). Most HR practitioners have used the concept of psychological contract to describe general trends in relation to employment between organization and employee (Wellin, 2007: 30).

According to Anderson and Schalk (1998), the intensification of research on psychological contracts has many environmental, organizational and individual reasons. Environmental and organizational reasons such as downsizing of businesses, global markets, technological developments, subcontracting; individual causes such as temporary / ongoing labor contracts, job insecurity, career, specialization and changes in ability management have led to an increased interest in psychological contract research (Anderson and Schalk, 1998, 637-647).

The number of studies on the concept of psychological contract in the world increases day by day; the studies are few in number and limited in Turkey. The researches carried out in Turkey reveals adverse effects on employees and organizations of the psychological contract breaches. In this study, the answer was searched to question of "Is there any effect on the performance of the psychological contract in health workers?". Accordingly, this study is important that because of the limited on the psychological contract studies in Turkey and the include all health professions the health sector.

\section{Research Methodology}

\section{Purpose of the Study}

The purpose of this study was to determine the level of psychological contract expectations, level of satisfaction by the institution and level of the psychological contract breach of the health professionals working in public and private hospitals and to determine whether there is any difference between them. In this main purpose research, it was tried to determine whether psychological contract levels differ according to hospital type and occupation variables.

\section{Scopes and Limits of the Study}

The research was carried out on health staff at the public hospitals and private hospitals in Gaziantep province center. This study was carried out on the professions of physicians, nurses, midwives, health technicians who were evaluated within the scope of health professionals. Other occupational groups working in hospitals are excluded from the scope of the research. In addition, employees who are on leave, sick or absent due to any reason during the data collection tool are excluded from the research.

\section{Model of the Study}

This research was done descriptively and cross-sectional. Within the scope of the research, psychological contracts and sub-dimensions (respect and honesty, support from the management and security, rewarding and offering opportunities) have been tried to determine the effect on employee performance. 


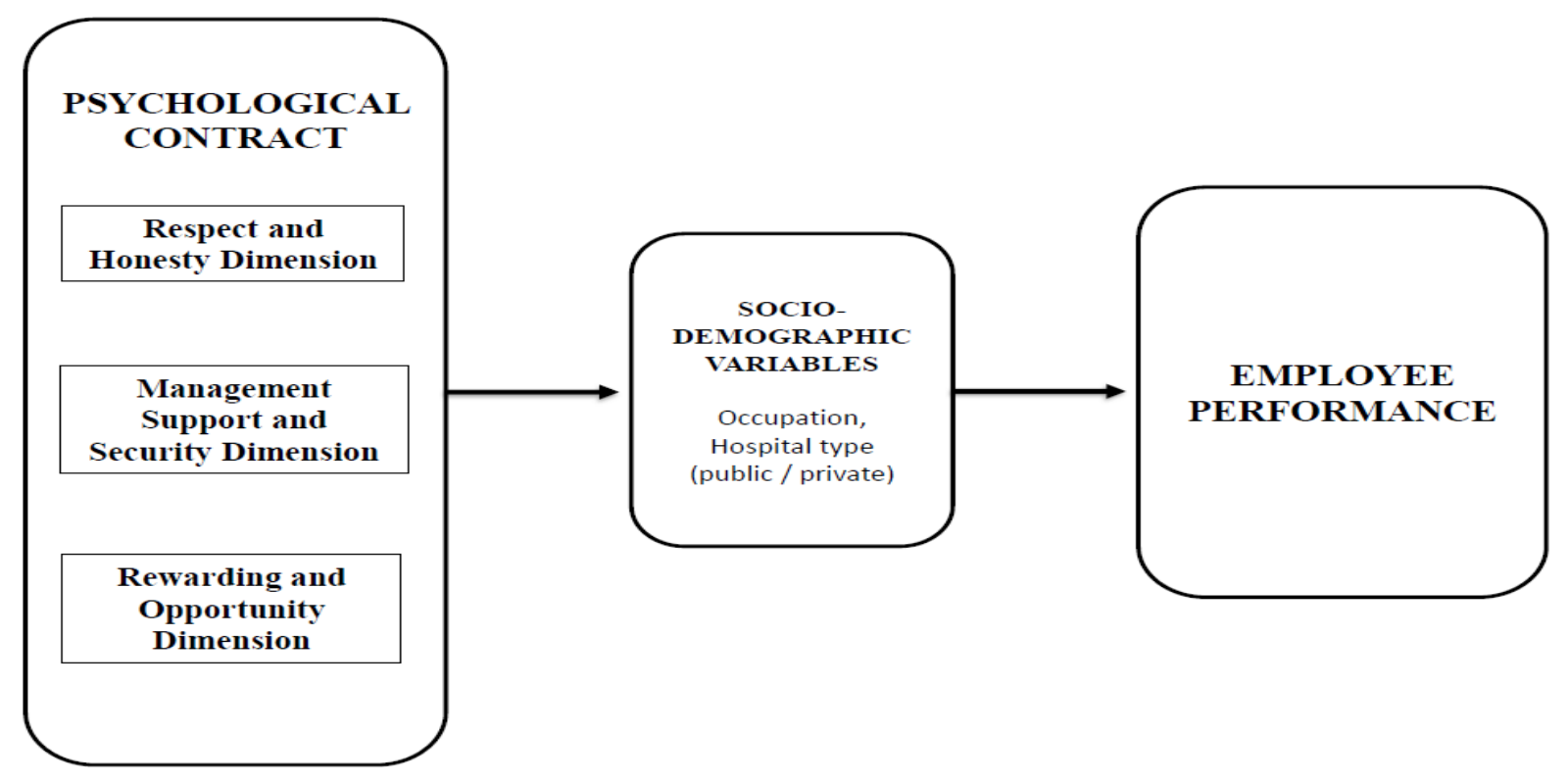

Figure 1. Model of the study

\section{Research Hypotheses}

Hypotheses developed to be tested according to the model and purpose of the research are as follows.

$\mathrm{H}_{1}=$ There is a statistically significant relationship between psychological contract employee expectations and employee performance.

$\mathrm{H}_{2}=$ There is a statistically significant relationship between level of satisfaction by the institution of the psychological contract and employee performance.

$\mathrm{H}_{3}=$ There is a statistically significant relationship between psychological contract breach and employee performance.

$\mathrm{H}_{4}=$ There is a statistically significant relationship between psychological contract employee expectations and level of satisfaction by the institution of the psychological contract.

$\mathrm{H}_{5}=$ There is a statistically significant relationship between psychological contract employee expectations and psychological contract breaches.

$\mathrm{H}_{6}=$ There is a statistically significant correlation between the level of satisfaction by the institution of the psychological contract and the level of psychological contract breach.

$\mathrm{H}_{7}=$ There is a statistically significant difference in psychological contract breach according to hospital type variable.

$\mathrm{H}_{8}=$ There is a statistically significant difference in psychological contract breach according to occupation variable. 


\section{Research Variables}

Independent variables of the study are the type of hospital (public / private hospital) and the occupation of the participants. Dependent variables of the study are psychological contract employee expectations, level of satisfaction by the institution and psychological contract breach and employee performance. The psychological contract consists of three sub-dimensions, respect and honesty, support from the management and security, rewarding and offering opportunities.

\section{Data Collection Method}

Survey method was used as data collection tool in the research. The data required for the study were obtained by conducting a face-to-face (personal interview) questionnaire on health workers who were randomly selected and volunteered to participate in the survey. The questionnaire consists of three question forms which personal information form, "Psychological Contract Scale" and "Employee Performance Scale". The questionnaire form contained 48 questions about socio-demographic, psychological contract and employee performance in part three. The questionnaires were analyzed using SPSS (Statistical Package for the Social Sciences) program. The employee performance scale was prepared as a 5-point likert type and it is scored as between "I strongly agree (5)", and "strongly disagree (1)".

\section{Psychological Contract Scale}

First developed by Denis Rousseau in 1992 "Psychological Contract Scale" is used in many researches in Turkey and the validity and reliability were tested (Saylor and Özkara, 2002; Özkeçel Flowers and Sea, 2005; Labor and Progressive, 2010). Psychological contract scale used to by İşçi and Artan was evaluated on three sub-dimensions ("factor of respect and honesty", "support and security from management" and "award and opportunity"). The Psychological Contract Scale consists of 32 elements; the scale score is the highest of 192 points and the lowest is 32 points. The low level of answers to the questionnaire suggests that the employee expectations are low and the level of satisfaction by the institution is low; the high scores indicate that employee expectations and level of satisfaction by the institution are high. The difference between the expectation and level of satisfaction by the institution of the employees in the organization reflects the level and level of the psychological contract breach.

\section{Employee Performance Scale}

"Employee Performance Scale", based on an article Rahman and Bullock (2004), used in some work in Turkey and its validity and reliability were determined (Şehitoğlu and Zehir, 2010; Kılınç and Ulusoy, 2014). The highest score that can be taken in the employee performance scale is 30 and the lowest score is 6 . The high score indicates that the employee is performing better. 
In the Psychological Contract Scale applied within the scope of the research, the psychological contract elements of the participant were asked in two ways as "The importance for you" and "The level of satisfaction by the workplace". Participants were asked to respond between 1 and 6 ( 1 being worst, 6 representing the best). From the responses of the participants, the level of psychological contract employee expectations, level of satisfaction by the institution and level of breach were tried to be revealed.

Cronbach alpha coefficients of Psychological Contract Scale and Employee Performance Scale were found as 0,978 and 0,782 respectively. This result shows that the reliability of the scales used in the research is highly reliable. SPSS program was used for the analysis of data in the study. Data were evaluated using frequency and percentage analyzes, factor analysis, difference'significance test of between two means (T test), ANOVA and correlation analysis and the level of error was taken as 0.05 .

\section{The Universe and Sample of Research}

In the study, written permission was taken from the related institutions for the questionnaire application. The distribution of the universe and sample of the research is given in Table 1 . The number of questionnaires applied and evaluated in our study is quite sufficient as it constitutes $23.61 \%$ of the main mass $(n=1.202)$ with an acceptable error rate of $2.47 \%$.

Table 1: The universe and sample of research

\begin{tabular}{|l|c|c|c|c|c|}
\hline \multirow{2}{*}{ Hospitals } & \multicolumn{2}{|c|}{ Universe } & \multicolumn{2}{|c|}{ Sample } & Universe/ sample \\
\cline { 2 - 6 } & $\mathrm{n}$ & $(\%)$ & $\mathrm{n}$ & $(\%)$ & $(\%)$ \\
\hline Private hospitals & 1.354 & 15.00 & 430 & 35.77 & 31.83 \\
\hline KHB hospitals & 2.991 & 79.59 & 676 & 87.56 & 22.60 \\
\hline University Medical Faculty hospitals & 767 & 20.41 & 96 & 12.44 & 3.21 \\
\hline Total & $\mathbf{5 . 1 1 2}$ & $\mathbf{1 0 0 . 0 0}$ & $\mathbf{1 . 2 0 2}$ & $\mathbf{1 0 0 . 0 0}$ & $\mathbf{2 3 . 6 1}$ \\
\hline
\end{tabular}

\section{Findings}

\section{Findings of the Research Group on Socio-Demographic Characteristics}

Table 2. Distribution of the study group according to socio-demographic characteristics

\begin{tabular}{lll}
\hline Socio-demographic characteristics & $(\mathbf{n})$ & $\mathbf{( \% )}$ \\
\hline Gender & & \\
\hline Woman & 780 & $\mathbf{6 4 . 9}$ \\
\hline Male & 422 & 35.1 \\
\hline Age groups & & \\
\hline Ages 16-20 & 112 & 9.3 \\
\hline Between the ages of 21-30 & 578 & $\mathbf{4 8 . 1}$ \\
\hline Between 31-40 years & 389 & $\mathbf{3 2 . 4}$ \\
\hline 41 and over & 123 & 10.2 \\
\hline
\end{tabular}




\begin{tabular}{|c|c|c|}
\hline Marital status & & \\
\hline Single & 648 & 53.9 \\
\hline The married & 554 & 46.1 \\
\hline \multicolumn{3}{|l|}{ Education status } \\
\hline High school & 282 & 23.5 \\
\hline Pre-license & 345 & 28.7 \\
\hline License & 328 & 27.3 \\
\hline Master's degree & 12 & 10.1 \\
\hline Doctorate & 125 & 10.4 \\
\hline \multicolumn{3}{|l|}{ Professional working years } \\
\hline $1-5$ years & 863 & 71.8 \\
\hline $6-10$ years & 223 & 18.6 \\
\hline 11 years and over & 116 & 9.7 \\
\hline \multicolumn{3}{|l|}{ Job } \\
\hline Nurse / health officer & 550 & 45.8 \\
\hline Midwife & 76 & 6.3 \\
\hline Health technician & 379 & 31.5 \\
\hline Physician & 197 & 16.4 \\
\hline \multicolumn{3}{|l|}{ Monthly income } \\
\hline Between 1.000-1999 TL & 362 & 30.1 \\
\hline Between 2000-2.999 TL & 536 & 44.6 \\
\hline$£ 3.000$ and over & 304 & 25.3 \\
\hline \multicolumn{3}{|l|}{ Number of workplaces } \\
\hline one & 159 & 20.6 \\
\hline 2nd & 263 & 34.1 \\
\hline 3 & 175 & 22.7 \\
\hline 4 and over & 174 & 22.5 \\
\hline \multicolumn{3}{|l|}{ Administrative task } \\
\hline Yes & 120 & 10 \\
\hline No & 1.082 & 90 \\
\hline Total & 1.202 & 100.0 \\
\hline
\end{tabular}

When the socio-demographic data of the participants were evaluated; $64.9 \%$ of the participants were women, $80.3 \%$ were in the age range of $21-40$ years, $53.9 \%$ were single, $53 \%$ were prelicense and licenses graduates, $71.8 \%$ have $1-5$ years professional work experience, $45.8 \%$ of were nurses, $44.6 \%$ of them have monthly income of $2.000-2.999 \mathrm{TL}$ and $10 \%$ of them have administrative duty.

\section{Findings related to the survey's scale}

Table 3. Distribution of overall score averages of research scales

\begin{tabular}{|l|c|c|c|c|}
\hline Scales & $\begin{array}{l}\text { Sayı } \\
(\mathbf{N})\end{array}$ & Min. & Max. & Mean+SD \\
\hline Respect and honesty & 1196 & 1 & 6 & $5.29 \pm 0.85$ \\
\hline Management support and security & 1196 & 1 & 6 & $5.27 \pm 0.90$ \\
\hline Reward and offer opportunities & 1195 & 1 & 6 & $5.30 \pm 0.90$ \\
\hline
\end{tabular}




\begin{tabular}{|l|c|c|c|c|}
\hline $\begin{array}{l}\text { Sum of psychological contract employee } \\
\text { expectations }\end{array}$ & 1195 & 1 & 6 & $5.26 \pm 0.92$ \\
\hline Respect and honesty & 1083 & 1 & 6 & $2.96 \pm 1.35$ \\
\hline Management support and security & 1078 & 1 & 6 & $2.95 \pm 1.38$ \\
\hline Reward and offer opportunities & 1078 & 1 & 6 & $3.11 \pm 1.36$ \\
\hline $\begin{array}{l}\text { Sum level of satisfaction by the institution of the } \\
\text { psychological contract }\end{array}$ & 1077 & 1 & 6 & $2.67 \pm 1.37$ \\
\hline Respect and honesty & 1196 & 1 & 6 & $2.64 \pm 1.67$ \\
\hline Management support and security & 1196 & 1 & 6 & $2.57 \pm 1.72$ \\
\hline Reward and offer opportunities & 1195 & 1 & 6 & $2.18 \pm 1.55$ \\
\hline Sum of psychological contract breach level & 1195 & 1 & 6 & $2.79 \pm 1.76$ \\
\hline Employee performance level & 1135 & 1 & 5 & $4.04 \pm 0.81$ \\
\hline
\end{tabular}

It has been revealed in Table 3 the overall score of psychological contract employee expectations, level of satisfaction by the institution of these expectations, psychological contract breach and employee performance. Sum of psychological contract employee expectations of is $5.26 \pm 0.92$ (max: 6 . min: 1); these expectancies were $2.67 \pm 1.37$ (max: 6 . min: 1) level of satisfaction by institution; the psychological contract breach was $2.79 \pm 1.76$ (max: 6. min: 1). It is also seen that the total level of performance of the employee is $4.04 \pm$ 0.81 (max: 5. min: 1). 


\section{Table 4. Correlation between psychological contract and employee performance variables}

\begin{tabular}{|c|c|c|c|c|c|c|c|c|c|c|c|c|c|c|}
\hline \multicolumn{2}{|c|}{ Scales and Factors } & \multicolumn{4}{|c|}{$\begin{array}{c}\text { Level of psychological contract employee } \\
\text { expectations }\end{array}$} & \multicolumn{4}{|c|}{$\begin{array}{c}\text { Level of satisfaction by institution of the } \\
\text { psychological contract }\end{array}$} & \multicolumn{4}{|c|}{ Level of psychological contract breach } & \multirow[b]{2}{*}{$\begin{array}{l}\text { Employee } \\
\text { Performance }\end{array}$} \\
\hline & & $\begin{array}{l}\text { Respect } \\
\text { and } \\
\text { honesty }\end{array}$ & $\begin{array}{l}\text { Management } \\
\text { support and } \\
\text { security }\end{array}$ & $\begin{array}{c}\text { Reward and } \\
\text { offer } \\
\text { opportunities }\end{array}$ & Total & $\begin{array}{l}\text { Respect } \\
\text { and } \\
\text { honesty }\end{array}$ & $\begin{array}{l}\text { Management } \\
\text { support and } \\
\text { security }\end{array}$ & $\begin{array}{c}\text { Reward and } \\
\text { offer } \\
\text { opportunities }\end{array}$ & Total & $\begin{array}{l}\text { Respect } \\
\text { and } \\
\text { honesty }\end{array}$ & $\begin{array}{l}\text { Management } \\
\text { support and } \\
\text { security }\end{array}$ & $\begin{array}{c}\text { Reward and } \\
\text { offer } \\
\text { opportunities }\end{array}$ & Total & \\
\hline \multirow{4}{*}{$\begin{array}{l}\text { Level of } \\
\text { psychological } \\
\text { contract } \\
\text { employee } \\
\text { expectations }\end{array}$} & $\begin{array}{l}\text { Respect and } \\
\text { honesty }\end{array}$ & & $.779(* *)$ & $.795(* *)$ & $.904(* *)$ & $-.068(*)$ & -.049 & $-.077(*)$ & $-.072(*)$ & $.398(* *)$ & $.261(* *)$ & $.327(* *)$ & $.348(* *)$ & $.063\left(^{*}\right)$ \\
\hline & $\begin{array}{l}\text { Management } \\
\text { support and } \\
\text { security }\end{array}$ & $.779(* *)$ & & $.909(* *)$ & $.943(* *)$ & -.054 & $-.062(*)$ & $-.101(* *)$ & $-.081(*)$ & $.294(* *)$ & $.398(* *)$ & $.419(* *)$ & $.393(* *)$ & $.079(* *)$ \\
\hline & $\begin{array}{l}\text { Reward and offer } \\
\text { opportunities }\end{array}$ & $.795(* *)$ & $.909(* *)$ & & $.969(* *)$ &.${ }^{-}(* *)$ & $-.119(* *)$ & $-.133(* *)$ & $-.130(* *)$ & $.334(* *)$ & $.386(* *)$ & $.484(* *)$ & $.433(* *)$ & $.078(*)$ \\
\hline & Total & $.904(* *)$ & $.943(* *)$ & $.969(* *)$ & & $\begin{array}{c}- \\
.087(* *)\end{array}$ & $-.094(* *)$ & $-.114(* *)$ & $-.109(* *)$ & $.357(* *)$ & $.366(* *)$ & $.438(* *)$ & $.413(* *)$ & $.079(* *)$ \\
\hline \multirow{4}{*}{$\begin{array}{c}\text { Level of } \\
\text { satisfaction } \\
\text { by institution } \\
\text { of the } \\
\text { psychological } \\
\text { contract }\end{array}$} & $\begin{array}{l}\text { Respect and } \\
\text { honesty }\end{array}$ & $-.068(*)$ & -.054 & $-.105(* *)$ & $-.087(* *)$ & & $.825(* *)$ & $.873(* *)$ & $.944(* *)$ & $.839^{-}(* *)$ & $-.682(* *)$ & $-.713(* *)$ & $-.781(* *)$ & $.088(* *)$ \\
\hline & $\begin{array}{l}\text { Management } \\
\text { support and } \\
\text { security }\end{array}$ & -.049 & $-.062(*)$ & $-.119(* *)$ & $-.094(* *)$ & $.825(* *)$ & & $.869(* *)$ & $.934(* *)$ & $\stackrel{-}{-} .686^{(* *)}$ & $-.835(* *)$ & $-.717(* *)$ & $-.774(* *)$ & $.064(*)$ \\
\hline & $\begin{array}{l}\text { Reward and offer } \\
\text { opportunities }\end{array}$ & $-.077(*)$ & $-.101(* *)$ & $-.133(* *)$ & $-.114(* *)$ & $.873(* *)$ & $.869(* *)$ & & $.972(* *)$ & $\begin{array}{c}- \\
.745^{(* *)}\end{array}$ & $-.750(* *)$ & $-.837(* *)$ & $-.827(* *)$ & $.092(* *)$ \\
\hline & Total & $-.072(*)$ & $-.081(*)$ & $-.130(* *)$ & $-.109(* *)$ & $.944(* *)$ & $.934(* *)$ & $.972(* *)$ & & $. \overline{-} .(* *)$ & $-.794(* *)$ & $-.809(* *)$ & $-.843(* *)$ & $.090(* *)$ \\
\hline \multirow{5}{*}{$\begin{array}{l}\text { Level of } \\
\text { psychological } \\
\text { contract } \\
\text { breach }\end{array}$} & $\begin{array}{l}\text { Respect and } \\
\text { honesty }\end{array}$ & $.398(* *)$ & $.294(* *)$ & $.334(* *)$ & $.357(* *)$ & $\begin{array}{c}- \\
.839(* *)\end{array}$ & $-.686(* *)$ & $-.745(* *)$ & $-.801(* *)$ & & $.825(* *)$ & $.860(* *)$ & $.936(* *)$ & -.030 \\
\hline & $\begin{array}{l}\text { Management } \\
\text { support and } \\
\text { security }\end{array}$ & $.261(* *)$ & $.398(* *)$ & $.386(* *)$ & $.366(* *)$ & 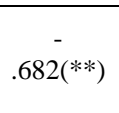 & $-.835(* *)$ & $-.750(* *)$ & $-.794(* *)$ & $.825(* *)$ & & $.904(* *)$ & $.945(* *)$ & -.008 \\
\hline & $\begin{array}{l}\text { Reward and offer } \\
\text { opportunities }\end{array}$ & $.327(* *)$ & $.419(* *)$ & $.484(* *)$ & $.438(* *)$ & $\begin{array}{c}- \\
.713(* *)\end{array}$ & $-.717(* *)$ & $-.837(* *)$ & $-.809(* *)$ & $.860(* *)$ & $.904(* *)$ & & $.976(* *)$ & -.027 \\
\hline & Total & $.348(* *)$ & $.393(* *)$ & $.433(* *)$ & $.413(* *)$ & $\begin{array}{r}- \\
.781(* *)\end{array}$ & $-.774(* *)$ & $-.827(* *)$ & $-.843(* *)$ & $.936(* *)$ & $.945(* *)$ & $.976(* *)$ & & -.025 \\
\hline & $\begin{array}{l}\text { Employee } \\
\text { Performance }\end{array}$ & $.063(*)$ & $.079(* *)$ & $.078\left(^{*}\right)$ & $.079(* *)$ & $.088(* *)$ & $.064(*)$ & $.092(* *)$ & $.090(* *)$ & -.030 & -.008 & -.027 & -.025 & \\
\hline
\end{tabular}


The correlations between the participants of the psychological contract of the participants. Level of satisfaction by institution of the psychological contract. psychological contract breach and employee performance and values factors are given in Table 4. The relationship between psychological contract employee expectations, level of satisfaction by the institution of the psychological contract, level of psychological contract breach and employee performance is given below.

\section{The general score of the employee expectations of the psychological contract scale;}

a) A statistically significant and inverse weak correlation was found between the general score of level of satisfaction by institution of the psychological contract $(\mathrm{r}=-0.109 * *)$ (this result implies the acceptance of the hypothesis $\mathrm{H}_{4}$ ).

b) A statistically significant and similar moderate relationship between the general score of psychological contract breach level $(\mathrm{r}=0.413 * *)$ (this result implies the acceptance of the $\mathrm{H}_{5}$ hypothesis).

c) A statistically significant and similar weak correlation was found between the overall score of the employee performance $(r=0.079 * *)$ (this implies the acceptance of the H1 hypothesis) $(\mathrm{p}<0.01)$.

\section{The general score of the level of satisfaction by institution of the psychological contract;}

a) A statistically significant positive and negative correlation was found between the overall score of the psychological contract breach level $\left(r=-0.843^{* *}\right)$ (this implies the acceptance of the $\mathrm{H}_{6}$ hypothesis).

b) A statistically significant and similar weak correlation was found between the general performance score $(\mathrm{r}=0.090 * *)(\mathrm{p}<0.01)$ (this implies the acceptance of the $\mathrm{H}_{2}$ hypothesis).

\section{The general score of the level of breach of the psychological contract scale;}

A statistically significant negative correlation was found between the general performance score $(\mathrm{r}=-0.025 * *)(\mathrm{p}<0.01)$ (this implies the acceptance of the $\mathrm{H}_{3}$ hypothesis). 
Table 5. Distribution of participants' psychological contracts and employee performance score averages by hospital types

\begin{tabular}{|c|c|c|c|c|c|}
\hline Scales & Dimensions & Hostital types & $\mathbf{N}$ & Mean+SD & $\begin{array}{c}\text { Student-t test } \\
\text { results }\end{array}$ \\
\hline \multirow{8}{*}{$\begin{array}{l}\text { Level of } \\
\text { psychological } \\
\text { contract } \\
\text { employee } \\
\text { expectations }\end{array}$} & \multirow{2}{*}{ Respect and honesty } & Private hospital & 421 & $5.39 \pm 0.78$ & $\mathrm{t}=3.63$ \\
\hline & & Public hospital & 747 & $5.21 \pm 0.95$ & $\mathrm{p}=0.001 *$ \\
\hline & \multirow{2}{*}{$\begin{array}{l}\text { Management support and } \\
\text { security }\end{array}$} & Private hospital & 422 & $5.41 \pm 0.76$ & $\mathrm{t}=3.52$ \\
\hline & & Public hospital & 750 & $5.23 \pm 0.96$ & $\mathrm{p}=0.002 *$ \\
\hline & \multirow{2}{*}{$\begin{array}{l}\text { Reward and offer } \\
\text { opportunities }\end{array}$} & Private hospital & 416 & $5.36 \pm 0.77$ & $t=3.06$ \\
\hline & & Public hospital & 742 & $5.20 \pm 0.99$ & $\mathrm{p}=0.002 *$ \\
\hline & \multirow{2}{*}{$\begin{array}{l}\text { Psychological contract } \\
\text { employee expectations } \\
\text { (total) }\end{array}$} & Private hospital & 411 & $5.39 \pm 0.72$ & $t=3.21$ \\
\hline & & Public hospital & 723 & $5.23 \pm 0.91$ & $\mathrm{p}=0.001 *$ \\
\hline \multirow{8}{*}{$\begin{array}{l}\text { Level of satisfaction } \\
\text { by institution of the } \\
\text { psychological } \\
\text { contract }\end{array}$} & \multirow{2}{*}{ Respect and honesty } & Private hospital & 390 & $3.51 \pm 1.52$ & $\mathrm{t}=10.06$ \\
\hline & & Public hospital & 658 & $2.61 \pm 1.17$ & $\mathrm{p}=0.001^{*}$ \\
\hline & \multirow{2}{*}{$\begin{array}{l}\text { Management support and } \\
\text { security }\end{array}$} & Private hospital & 393 & $3.62 \pm 1.46$ & $t=9.43$ \\
\hline & & Public hospital & 662 & $2.80 \pm 1.19$ & $\mathrm{p}=0.001 *$ \\
\hline & \multirow{2}{*}{$\begin{array}{l}\text { Reward and offer } \\
\text { opportunities }\end{array}$} & Private hospital & 391 & $3.22 \pm 1.53$ & $t=9.75$ \\
\hline & & Public hospital & 654 & $2.35 \pm 1.14$ & $\mathrm{p}=0.001 *$ \\
\hline & \multirow{2}{*}{$\begin{array}{l}\text { Satisfaction by institution of } \\
\text { psychological contract } \\
\text { (total) }\end{array}$} & Private hospital & 383 & $3.52 \pm 1.50$ & $\mathrm{t}=10.15$ \\
\hline & & Public hospital & 639 & $2.62 \pm 1.13$ & $\mathrm{p}=0.001 *$ \\
\hline \multirow{8}{*}{$\begin{array}{l}\text { Level of } \\
\text { psychological } \\
\text { contract breach }\end{array}$} & \multirow{2}{*}{ Respect and honesty } & Private hospital & 430 & $2.07 \pm 1.79$ & $\mathrm{t}=-7.48$ \\
\hline & & Public hospital & 772 & $2.85 \pm 1.62$ & $\mathrm{p}=0.001 *$ \\
\hline & \multirow{2}{*}{$\begin{array}{l}\text { Management support and } \\
\text { security }\end{array}$} & Private hospital & 430 & $1.78 \pm 1.60$ & $t=-6.80$ \\
\hline & & Public hospital & 772 & $2.41 \pm 1.47$ & $\mathrm{p}=0.001 *$ \\
\hline & \multirow{2}{*}{$\begin{array}{l}\text { Reward and offer } \\
\text { opportunities }\end{array}$} & Private hospital & 430 & $2.30 \pm 1.83$ & $t=-7.39$ \\
\hline & & Public hospital & 772 & $3.06 \pm 1.66$ & $\mathrm{p}=0.001 *$ \\
\hline & \multirow{2}{*}{$\begin{array}{l}\text { Psychological contract } \\
\text { breach level (total) }\end{array}$} & Private hospital & 430 & $2.15 \pm 1.74$ & $\mathrm{t}=-7.49$ \\
\hline & & Public hospital & 772 & $2.91 \pm 1.56$ & $\mathrm{p}=0.001 *$ \\
\hline \multirow{2}{*}{$\begin{array}{l}\text { Employee } \\
\text { Performance } \\
\text { Level } \\
\end{array}$} & \multirow[b]{2}{*}{ Employee Performance } & Private hospital & 392 & $4.21 \pm 0.79$ & $\mathrm{t}=5.45$ \\
\hline & & Public hospital & 740 & $3.94 \pm 0.80$ & $\mathrm{p}=0.001 *$ \\
\hline
\end{tabular}

$* \mathrm{p}<0.01$

Psychological contract employee expectations, level of satisfaction by institution of the psychological contract, psychological contract breach level and employee performance distributions according to hospital type of study participants are given in table 5. When psychological contract scores were evaluated according to hospital type. there was a statistically significant difference between those working in public hospitals and those working in private hospitals ( $\mathrm{p}<0.01)$. These differences are given below.

a) It was found that the healthcare workers $(5.39 \pm 0.72)$ working in the private sector hospitals had a higher level of psychological contract employee expectations than the health workers $(5.23 \pm 0.91)$ working in the public hospitals $(\mathrm{df}=1017.24)=3.21 ; \mathrm{p}=0.001 \& \mathrm{lt} ; 0.01)$. 
b) The private hospital employees were found to have met higher level of psychological contract employee expectations by the institutions $(\mathrm{df}=642.56)=10 . \mathrm{p}<0.05)$ than the public hospital employees $(3.52 \pm 1.50) 15 ; \mathrm{p}=0.001 \& \mathrm{lt} ; 0.01)$.

c) Public hospital employees were found to have higher levels of psychological contract breaches $(2.91 \pm 1.56)$ than private hospital employees $(2.15 \pm 1.74)(\mathrm{t}(\mathrm{df}=812.25)=-7.49 ; \mathrm{p}$ $=0.001<0.01)$ (These results indicate that the $\mathrm{H}_{7}$ hypothesis has been accepted).

A statistically significant difference was found in the performance of the participants in the study according to the hospital type.

Table 6. Participants' psychological contract and occupational performance score averages

\begin{tabular}{|c|c|c|c|c|c|c|}
\hline & Dimensions & Occupations & $\mathbf{N}$ & Mean+SD & $\begin{array}{l}\text { Min- } \\
\text { Max }\end{array}$ & $\begin{array}{l}\text { Anova test } \\
\text { results }\end{array}$ \\
\hline \multirow{20}{*}{ 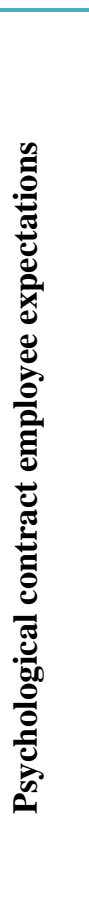 } & \multirow[t]{5}{*}{ Respect and honesty } & Nurse & 536 & $5.44 \pm 0.78$ & $1-6$ & \multirow{5}{*}{$F=33.03$} \\
\hline & & Midwife & 75 & $5.48 \pm 0.69$ & $1-6$ & \\
\hline & & Health Tech. & 368 & $5.25 \pm 0.87$ & $1-6$ & \\
\hline & & Physician & 189 & $4.76 \pm 1.10$ & $1-6$ & \\
\hline & & Total & 1168 & $5.27 \pm 0.90$ & $1-6$ & \\
\hline & \multirow{5}{*}{$\begin{array}{l}\text { Management } \\
\text { support and security }\end{array}$} & Nurse & 535 & $5.48 \pm 0.74$ & $1-6$ & \multirow{5}{*}{$\mathrm{p}=0.001 *$} \\
\hline & & midwife & 76 & $5.50 \pm 0.76$ & $1-6$ & \\
\hline & & Health Tech. & 368 & $5.25 \pm 0.91$ & $1-6$ & \\
\hline & & Physician & 193 & $4.79 \pm 1.09$ & $1-6$ & \\
\hline & & Total & 1172 & $5.30 \pm 0.90$ & $1-6$ & \\
\hline & \multirow{5}{*}{$\begin{array}{l}\text { Reward and offer } \\
\text { opportunities }\end{array}$} & Nurse & 528 & $5.45 \pm 0.76$ & $1-6$ & \multirow{5}{*}{$\mathrm{F}=27.75$} \\
\hline & & Midwife & 76 & $5.38 \pm 1.00$ & $1-6$ & \\
\hline & & Health Tech. & 369 & $5.21 \pm 0.95$ & $1-6$ & \\
\hline & & Physician & 185 & $4.76 \pm 1.06$ & $1-6$ & \\
\hline & & Total & 1158 & $5.26 \pm 0.92$ & $1-6$ & \\
\hline & \multirow{5}{*}{$\begin{array}{l}\text { Psychological } \\
\text { contract employee } \\
\text { expectations (total) }\end{array}$} & Nurse & 521 & $5.47 \pm 0.68$ & $1-6$ & \multirow{5}{*}{$\mathrm{p}=0.001^{*}$} \\
\hline & & Midwife & 75 & $5.44 \pm 0.81$ & $1-6$ & \\
\hline & & Health Tech. & 360 & $5.24 \pm 0.85$ & $1-6$ & \\
\hline & & Physician & 178 & $4.77 \pm 1.05$ & $1-6$ & \\
\hline & & Total & 1134 & $5.29 \pm 0.85$ & $1-6$ & \\
\hline \multirow{16}{*}{ 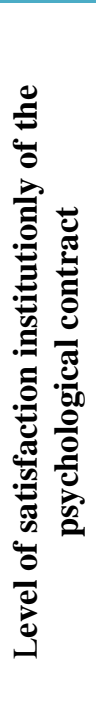 } & \multirow[t]{5}{*}{ Respect and honesty } & Nurse & 488 & $2.76 \pm 1.39$ & $1-6$ & \multirow{5}{*}{$\mathrm{F}=13.13$} \\
\hline & & Midwife & 70 & $3.29 \pm 1.35$ & $1-6$ & \\
\hline & & Health Tech. & 346 & $2.90 \pm 1.35$ & $1-6$ & \\
\hline & & Physician & 144 & $3.52 \pm 1.26$ & $1-6$ & \\
\hline & & Total & 1048 & $2.95 \pm 1.38$ & $1-6$ & \\
\hline & \multirow{5}{*}{$\begin{array}{l}\text { Management } \\
\text { support and security }\end{array}$} & Nurse & 489 & $2.95 \pm 1.38$ & $1-6$ & \multirow{5}{*}{$\begin{array}{l}\mathrm{F}=7.66 \\
\mathrm{p}=0.001 *\end{array}$} \\
\hline & & Midwife & 71 & $3.27 \pm 1.31$ & $1-6$ & \\
\hline & & Health Tech. & 351 & $3.11 \pm 1.37$ & $1-6$ & \\
\hline & & Physician & 144 & $3.54 \pm 1.14$ & $1-6$ & \\
\hline & & Total & 1055 & $3.10 \pm 1.36$ & $1-6$ & \\
\hline & \multirow{5}{*}{$\begin{array}{l}\text { Reward and offer } \\
\text { opportunities }\end{array}$} & Nurse & 489 & $2.50 \pm 1.38$ & $1-6$ & \multirow{5}{*}{$\begin{array}{l}\mathrm{F}=11.45 \\
\mathrm{p}=0.001 *\end{array}$} \\
\hline & & Midwife & 70 & $2.83 \pm 1.30$ & $1-6$ & \\
\hline & & Health Tech. & 341 & $2.65 \pm 1.35$ & $1-6$ & \\
\hline & & Physician & 145 & $3.24 \pm 1.23$ & $1-6$ & \\
\hline & & Total & 1045 & $2.67 \pm 1.37$ & $1-6$ & \\
\hline & & Nurse & 478 & $2.78 \pm 1.38$ & $1-6$ & $\mathrm{~F}=11.52$ \\
\hline
\end{tabular}




\begin{tabular}{|l|l|l|r|r|c||}
\hline \multirow{2}{*}{$\begin{array}{l}\text { Level of } \\
\text { satisfaction by } \\
\text { institution of } \\
\text { psychological } \\
\text { contract (total) }\end{array}$} & Midwife & 70 & $3.18 \pm 1.28$ & $1-6$ & \multirow{2}{*}{$\mathrm{p}=0.001 *$} \\
\cline { 2 - 5 } & Health Tech. & 337 & $2.93 \pm 1.33$ & $1-6$ & $1-6$ \\
\cline { 2 - 5 } & Physician & 137 & $3.51 \pm 1.20$ & \\
\cline { 2 - 5 } & Total & 1022 & $2.95 \pm 1.35$ & $1-6$ & \\
\hline
\end{tabular}

Table 6. Participants' psychological contract and occupational performance score averages (continued)

\begin{tabular}{|c|c|c|c|c|c|c|}
\hline & Dimensions & Occupations & $\mathbf{N}$ & Mean+SD & $\begin{array}{l}\text { Min- } \\
\text { Max }\end{array}$ & $\begin{array}{l}\text { Anova test } \\
\text { results }\end{array}$ \\
\hline \multirow{20}{*}{ 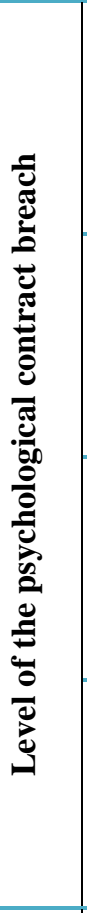 } & \multirow{5}{*}{$\begin{array}{l}\text { Respect and } \\
\text { honesty }\end{array}$} & Nurse & 550 & $2.85 \pm 1.78$ & $1-6$ & \multirow{5}{*}{$\mathrm{F}=12.51$} \\
\hline & & Midwife & 76 & $2.40 \pm 1.64$ & $1-6$ & \\
\hline & & Health Tech. & 379 & $2.49 \pm 1.65$ & $1-6$ & \\
\hline & & Physician & 197 & $2.02 \pm 1.56$ & $1-6$ & \\
\hline & & Total & 1202 & $2.57 \pm 1.72$ & $1-6$ & \\
\hline & \multirow{5}{*}{$\begin{array}{l}\text { Management } \\
\text { support and } \\
\text { security }\end{array}$} & Nurse & 550 & $2.42 \pm 1.56$ & $1-6$ & \multirow{5}{*}{$\begin{array}{l}\mathrm{F}=8.86 \\
\mathrm{p}=0.001 *\end{array}$} \\
\hline & & Midwife & 76 & $2.18 \pm 1.51$ & $1-6$ & \\
\hline & & Health Tech. & 379 & $2.03 \pm 1.55$ & $1-6$ & \\
\hline & & Physician & 197 & $1.84 \pm 1.42$ & $1-6$ & \\
\hline & & Total & 1202 & $2.18 \pm 1.55$ & $1-6$ & \\
\hline & \multirow{5}{*}{$\begin{array}{l}\text { Reward and } \\
\text { offer } \\
\text { opportunities }\end{array}$} & Nurse & 550 & $3.07 \pm 1.77$ & $1-6$ & \multirow{5}{*}{$\begin{array}{l}\mathrm{F}=12.40 \\
\mathrm{p}=0.001 *\end{array}$} \\
\hline & & Midwife & 76 & $2.75 \pm 1.81$ & $1-6$ & \\
\hline & & Health Tech. & 379 & $2.68 \pm 1.73$ & $1-6$ & \\
\hline & & Physician & 197 & $2.22 \pm 1.65$ & $1-6$ & \\
\hline & & Total & 1202 & $2.79 \pm 1.76$ & $1-6$ & \\
\hline & \multirow{5}{*}{$\begin{array}{l}\text { Psychological } \\
\text { contract } \\
\text { breach (total) }\end{array}$} & Nurse & 550 & $2.92 \pm 1.70$ & $1-6$ & \multirow{5}{*}{$\begin{array}{l}\mathrm{F}=12.41 \\
\mathrm{p}=0.001 *\end{array}$} \\
\hline & & Midwife & 76 & $2.57 \pm 1.64$ & $1-6$ & \\
\hline & & Health Tech. & 379 & $2.52 \pm 1.61$ & $1-6$ & \\
\hline & & Physician & 197 & $2.12 \pm 1.55$ & $1-6$ & \\
\hline & & Total & 1202 & $2.64 \pm 1.67$ & $1-6$ & \\
\hline \multirow{5}{*}{ 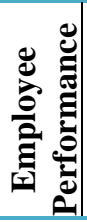 } & \multirow{5}{*}{$\begin{array}{l}\text { Employee } \\
\text { Performance }\end{array}$} & Nurse & 512 & $4.05 \pm 0.79$ & $1-6$ & \multirow{5}{*}{$\mathrm{p}=0.974$} \\
\hline & & Midwife & 73 & $4.03 \pm 0.93$ & $1-6$ & \\
\hline & & Health Tech. & 361 & $4.02 \pm 0.82$ & $1-6$ & \\
\hline & & Physician & 186 & $4.05 \pm 0.78$ & $1-6$ & \\
\hline & & Total & 1132 & $4.04 \pm 0.81$ & $1-6$ & \\
\hline
\end{tabular}

Psychological contracting employee expectations, level of satisfaction by the institution of the psychological contract, psychological contract breach and employee performance distributions according to participants' professions are given in table 6. A statistically significant difference was found between level of satisfaction by the institution of psychological contracting and level of the psychological contract breach according to the occupations of the participants ( $<<0.01$ ). This means that the $\mathrm{H}_{8}$ hypothesis has been accepted. The Tukey test revealed that there were significant differences between the occupations. The results are given below.

a) Psychological contract expectations of nurses $(5.47 \pm 0.68)$, midwives $(5.44 \pm 0.81)$ and health technicians $(5.24 \pm 0.85)$ were higher than physicians $(4.77 \pm 1.05)(\mathrm{p}<0.01)$. 
b) The psychiatric contracts of physicians $(3.51 \pm 1.20)$ were higher than the nurses $(2.78 \pm$ $1.38)$, health technicians $(2.93 \pm 1.33)$ and midwives $(3.18 \pm 1.28)$ respectively $(\mathrm{p}<0.01)$.

c) Nurses $(2.92 \pm 1.70)(\mathrm{p}<0.01)$ and health technicians $(2.85 \pm 1.28)(\mathrm{p}<0.05)$ were higher more than doctors $(2.12 \pm 1.55)$ psychological contract breaches.

\section{Discussion, Conclusion and Recommendations}

Psychological contract is a set of non-written, time-varying, reciprocal-based, individualized mental expectations that explain the nature of the employment relationship between the employer and the employee and explain the expectations and realizations of the individual and the work relationship. The concept of psychological contract has recently become a concept that has been studied on different sectors and wider samples. When the studies carried out in Turkey on the psychological contract is a small number of research and specific sectors / it is seen to include occupational groups. The results of the research are compared with some studies (İşçi and Artan, 2010; Türker and Karcıoğlu, 2010; Ceseroğlu and Tükeltürk, 2010; Ahmed et

all., 2016; Rodwell and Gulyas, 2015), because psychological contract studies on all health professionals in the health sector (public and private) are limited.

The results of the study are as follows:

1) The increase in psychological contract employee expectations partially reduces level of satisfaction by the institution of the psychological contract; the level of psychological contract breach is moderate and the performance of the employee is also partially increased (and vice versa).

2) The increase in level of satisfaction by the institution of the psychological contract reduces the psychological contract breaches at high rates (and vice versa).

3) The increase in the level of psychological contract breach scale also partially reduces employee performance (and vice versa).

4) When the answers given by all of the research participants are evaluated; it is seen that there is a significant amount of difference between the psychological contract employee expectations and the level of satisfaction by the institution of the psychological contract. The biggest difference here (breach) is the psychological contractor's reward and opportunity $(2.79 \pm 1.76)$ dimension; the lowest difference is management support and job security $(2.57 \pm 1.72)$. Similar to this stud, the survey of 450 nurses by İşçi and Artan (2010) showed that the participants were mostly in the dimension of awarding psychological contract breaches and presenting opportunities $(2.79 \pm 1.76)$; it is seen that at least psychological contract breach $(1.51 \pm 1.18)$ participates in management support and job security dimension (İşçi and Artan. 2010). Ahmed et al. (2016:152) presented breach of psychological contract and organizational injustice have been found to have significant positive impact upon their counterproductive behavior. According to 
Rodwell and Gulyas (2015: 142), the findings suggest that PC breach may negatively impact organisational commitment and well-being, which may be due to its effects on employees' emotions (Rodwell and Gulyas, 2015: 402). The fact that level of satisfaction by the institution of the psychological contract is low in the 'reward and opportunity' dimension and the participants' psychological contract bs are the most at this factor indicates that the employees do not adequately meet the material and moral rewards and incentives and do not give employees enough opportunities and opportunities in the workplace.

5) When psychological contract and employee performance scores were evaluated according to hospital type, statistically significant differences were found between public and private hospital employees $(\mathrm{p}<0.01)$. These differences are given below.

$\checkmark$ Private hospital employees levels of psychological contract expectations had higher than public hospital employees $(p=0.001<0.01)$.

$\checkmark$ Psychological contract expectations in private hospital employees are higher than public private hospital employees $(\mathrm{p}=0.001<0.01)$.

$\checkmark$ Public hospital employees level of psychological contract breach are at a higher than private hospital employees $(\mathrm{p}=0.001<0.01)$.

$\checkmark$ Private hospital employees performance have higher than public private hospital employees $(\mathrm{p}<0.01)$.

6) When psychological contract and employee performance scores were evaluated according to occupations of the participants, statistically significant differences were found between public and private hospital employees $(\mathrm{p}<0.01)$. These differences are given below.

$\checkmark$ Psychological contract expectations of nurses, midwives and health technicians had higher than doctors $(\mathrm{p}<0.01)$.

$\checkmark$ Level of satisfaction by institution of the psychological contract of physicians had higher than nurses. midwives and health technicians.

$\checkmark$ Psychological contract breach level of nurses $(\mathrm{p}<0.01)$ and health technicians (p $<0.05)$ had higher than doctors.

$\checkmark$ There was no significant difference in terms of worker performance according to their profession ( $\mathrm{p}>0.05)$.

$\checkmark$ Türker and Karcioğlu (2010) found a significant difference in the level of psychological contract compliance perceptions among the professions working on the health workers. Psychological contract compliance perceptions of nurses were found to be lower than doctors. Ceseroğlu and Tükeltürk (2010) did not find any significant difference between the work done on the hotel employees and the relational psychological contract averages according to the occupation variable in the workplace ( $p>0.05)$. Ahmed et al. (2016) presented the doctors have been found 
comparatively more deviant than the nurses are as they have higher expectations in terms of pay and fringe benefits than nurses do (Ahmed et al., 2016:152).

The following are suggestions that can be given in order to prevent breaches of psychological contracts according to research results and literature and to increase employee performance.

a) The employee expectations in the workplace must be determined correctly from the first day of employment. taking into account their job positions; these expectations should be considered when implementing organizational goals, human resources strategies and practices. Systematic studies should be carried out taking into consideration feedback to learn employee expectations. For this, a positive working atmosphere should be established to gain the trust of employees; employees should be trusted to their colleagues and managers.

b) Managers should know that the psychological contract is of personal perception and differs from person to person; they should also be avoided in this regard by prejudice and generalizations.

c) A clear meta-contract must be established to be applied across the workplace. This metacontract should provide a clear exchange of information to the parties in order to obtain information about their interests, objectives and constraints. Workplace rules should be clear and understandable in order to establish the right psychological contracts in the workplace.

d) Managers should come together with employees at certain times; these meetings should be held in the form of informing, sharing information and receiving the expectations of the parties. On this account, employees can express emotions, thoughts, beliefs and ideals to open-minded managers. Managers can also convey expectations from employees.

e) Future studies in different cities will be important in measuring the impact of the psychological contract on health workers and comparing them with the results of this research. From this point of view, it is thought that the results obtained will give a light to future studies.

\section{References}

Ahmed. I. Ramzan. M. Mohammad. S. K. \&Islam. T. (2011). Relationship between perceived fairness in performanceappraisal and OCB: Mediating Role of Organizational Commitment. International Journal of Academic Research.

Ahmed, W., Kiyani, A., \& Hashmi, S. (2016). The study on organizational cynicism, organizational injustice \& breach of psychological contract as the determinants of deviant work behavior.

Akyüz. N. E. and Karadal. H. (2014). Relationship between psychological contract and organizational identification Ankara PTT Headdirectorate office. Aksaray University. Institute of Social Sciences. Master Thesis. 
Anderson. N. and Schalk. R. (1998). The Psychological Contract in Retrospect and Prospect. Journal of Organizational Behavior. 19. 637-647.

Bedük. A. (2014). Organizational Psychology. Konya: Atlas Akademi.

Bekele. A. Z. Shigutu. A. D. \& Tensay. A. T. (2014). The effect of employees' perception of performance appraisal on their work outcomes. International Journal of Management and Commerce Innovations. 2(1). 136-173.

Brown. M. Hyatt. D. \& Benson. J. (2010). Consequences of the performance appraisal experience. Personnel review. 39(3). 375-396.

Ceseroğlu. C. M and Aydın Tükeltürk. Ş. (2010). The Impact on psychological contract and organizational commitment in terms of employee relations in organizations: sample of 4-5 star hotel establishments. Çanakkale Onsekiz Mart University. Institute of Social Sciences. Master Thesis.

Cihangiroğlu. N and Şahin. B. (2010). An Important phenomenon in organizations: psychological contract. ZKÜ Journal of Social Sciences. 6(11). 1-16.

Cihangiroğlu. N. and Şahin. B. (2012). Comparison of psychological contract perceptions of physicians and nurses " TAF Preventive Medicine Bulletin. 11(1). 63-70.

Cipd. (2005) The Psychological Contract: What It is. Why It's Important. How to Manage and Use It" West of Scotland Masterclass Series.

Coyle. S. Jacqueline. A.-M and Parzefall. M.-R. (2008) "The SAGE Handbook of Organizational Behavior" London.

Crossman. A. (2002) "Critical incidents and the dynamics of the psychological contract" British Academy of Management Conference. London: The Anahuac Journal. 55-66.

Dikili. A. and Bayraktaroğlu. S. (2013). A Research on psychological contract and job satisfaction. Eskişehir Osmangazi University. Journal of Economics and Administrative Sciences. 8 (2).

European Commission . R. (2006). Psychological contracts across employment situations. European Commission.

George. C. (2009). The Psychloogical contract. managing and developing groups. Berkshire. England: Open University Press. 
Geylan. R. Tonus. H. Kağnıcıoğlu. D. Benligiray. S. Baraz. A. and Ergün Özler. D. (2013) "Human Resources Management" Eskişehir: Anadou University. Açık̋̈ğretim Faculty.

Işılay Üçok. D and Alev Torun. A. (2012). The Impact of sinic attitude and psychological contract violation perception on burnout. Marmara University. Institute of Social Sciences. Master Thesis.

İşçi. E. and Artan. İ. (2010) " The Role of confidence in the 1mpact of the psychological convention violation on the organizational citizenship behavior and separation intention. Marmara University. Faculty of Social Sciences. Doctorate Thesis.

Karcıoğlu. F and Türker. E. (2010). Relationship between psychological contract and organizational commitment. an application on healthcare workers. Ataturk University Journal of Economics and Administrative Sciences. 24(2). 121-140.

Kaldırımcı. N. (1987). Keywords for motivation: psychological contract. Ataturk University. SBE Journal. 113-128.

Kılınç. E. Ulusoy. H. (2012). Investigation of organizational citizenship behavior. organizational silence and employee performance at physicians and nurses. and the relationship among them. Sivas Cumhuriyet University. Institute of Health Sciences. Master Thesis.

Kidder. D. L.and Buchholtz. A. K. (2002). Can excess bring success? CEO compensation and the psychological contract. Human Resource Management Review. 12. 599-617.

Kraft. J. M. (2008). Psychological contracts and organizational commitment profiles: Effects of contract fulfillment and violation on employee outcomes. Univerity of Windsor. Canada. Recuperado de http://www1. uwindsor. ca/people/ckwantes/system/files/ Kraft\% 20MA\% 20Thesis. pdf.

Lambert. L. Edwards. J and Cable. D. (2003). Breach and fulfillment of the psychological contract: a comparison of traditional and expanded views. Personnel Psychology. 56(4). 895-934.

Mimaroğlu Özgen. H. and Özgen. H. (2010). The Effects of psychological contract and dimensions on job satisfaction. organizational commitment and intent to leave: a survey on medical sales representatives. Cukurova University. Journal of Social Sciences Institute 19(1). 1-19. 
Özer M. and Bakır B. Determination of factors related to motivation of health personnel. Gülhane Medical Journal. 2003;45(2):11

Prather. T. (2010). The Perception of fairness of performance appraisals. Doctoral dissertation. Cleveland State University.

Ripley D. (2002). Improving Employee Performance Moving Beyond Traditional HRM Responses.

Robinson. S.and Rousseau. D. (1994). Violating the psychological contract: not the exception but the norm. Journal of Organizational Behavior. 15(3). 245-259.

Rodwell, J., \& Gulyas, A. (2015). Psychological contract breach among allied health professionals: Fairness, individual differences and an aggravated breach effect. Journal of health organization and management, 29(3), 393-412.Rousseau. D. (2000). Psychological contract inventory technical report.

Şehitoğlu. Y. and Zehir. C. (2010). The Analysis of employee performance in the context of employee silence and organizational citizenship behaviour in turkish public institutions. Amme İdaresi Journal. 43(4). 87-110.

Tengilimoğlu. D. Akbolat. M and Işık. O. (2009). Health Business Administration. İstanbul: Nobel Publication Distribution.

Tutar. H. and Altınöz. M. (2010). The Impact of organizational climate on occupational performance: a research on ostim manufacturing employees. Ankara University SBF Magazine Volume 65. Issue 2

Türk. M. (2007). Organizational Culture and Job Satisfaction. Ankara: Gazi Bookstore.

Türker. E and Karcioğlu. F. (2010). An application on the relationship between organizational commitment and psychological contract health workers. Ataturk University. Institute of Social Sciences. Master Thesis.

Wellin. M. (2007). Managing the psychloogical contract. Hampshire. England: Gouer Publishing Limited.

Wright. R.P. (2004). Mapping cognitions to better understand attitudinal and behavioral responses in appraisal research. Journal of Organizational Behavior. 25(3). 339-374.

Yavan. Ö. (2012). Strategic human resources management and company performance. Akademik Bakış Magazine. issue: 32. 1-20. 
Yorgun. S. Demir. Y. Süzük. S. Yıldırım Usta. Y. and Şentürk. E. (2010). Performance and quality of service according to the high performance institutions in the nation "II. International Performance and Quality in Health Quality Congress Report Book. Ankara. 353-361. 